\title{
ANALÝZA SPOTREBITELSKÉHO SPRÁVANIA RESPONDENTOV PRI NÁKUPE ŠPORTOVÉHO VYBAVENIA A DOPLNKOV
}

\author{
Filip Bajza ${ }^{1}$
}

\begin{abstract}
At present, concepts such as sustainability, IoT or environmental protection are increasingly mentioned in connection with retail. The aim of the paper is to find out which factors have the greatest influence on consumer behavior when choosing a particular online store and whether consumer behavior would be influenced by the implementation of the Internet of Things and the concept of sustainability.
\end{abstract}

Keywords: e-commerce, IoT, shopping behavior, sustainability

\section{Úvod}

Využívanie smart technológií a high-tech riešení je v trend, ktorý je schopný pozítívne ovplyvnit' efektívnost', konkurencieschopnost' a výkonnost' podnikov. Medzi takéto riešenia patrí napríklad internet vecí (IoT), ktorého riešenia je možné implementovat' takmer vo všetkých oblastiach. Nové technológie, zariadenia a optimalizácia existujúcich riešení podporuje možnost' implementácie internetu vecí aj v rámci maloobchodu. Medzi d'alšie prínosy implementácie IoT patria riešenia, ktoré napríklad podporujú koncept udržatel'nosti a znižovanie negatívnych vplyvov na životné prostredie. Podniky však môžu implementáciou high-tech riešení získat' konkurenčnú výhodu, vyššiu flexibilnost' a viditel'nost' jednotlivých procesov a v konečnom dôsledku aj spokojnost' svojich zákazníkov. Správanie spotrebitelov je však rozličné. Pri výbere predajne, kde budú spotrebitelia nakupovat', vystupuje viacero faktorov, ktoré majú vplyv na nákupné správanie spotrebitel’ov. Okrem tradičných faktorov ako je cena alebo kvalita produktov môže mat' vplyv na spotrebitel'ské správanie aj implementácia nových technológií a konceptov. Dôležité je však zistit', či by bol tento vplyv pozitívny alebo negatívny, resp. či by bol silnejší ako vplyv tradičných faktorov.

\section{Teoretický rámec}

Elektronický obchod je pojem, ktorý reprezentuje predaj alebo nákup tovarov a služieb prostredníctvom internetu a prenos peňazí a údajov potrebných $\mathrm{k}$ realizácii týchto činností. Niekedy sa pojem elektronický obchod používa v súvislosti len s predajom fyzických produktov online, avšak tento pojem reprezentuje všetky druhy obchodných transakcií realizovaných prostredníctvom internetu. Vd'aka elektronickému obchodu si môže ktokol'vek a kedykol'vek prostredníctvom rôznych technologických prostriedkov prezerat' ponuku jednotlivých podnikov a obchodov. Medzi výhody elektronického obchodu patrí napríklad takmer nepretržitá dostupnost', rýchlost' nákupu, širšia ponuka produktov, medzinárodný dosah alebo nižšia cena. Napriek tomu, že popularita nakupovania prostredníctvom internetu neustále rastie, elektronický obchod má aj nevýhody, medzi ktoré patrí napríklad obmedzený zákaznícky servis, čakacia doba, možnost' kybernetických útokov alebo nedostatočný popis

\footnotetext{
${ }^{1}$ Ing. Filip Bajza, Katedra spojov, FPEDAS, Žilinská univerzita v Žiline, e-mail: filip.bajza@stud.uniza.sk
} 
a znázornenie produktov. S rastom konkurencie nielen medzi internetovými a kamennými predajňami sa snažia podniky hl'adat' inovatívne high-tech riešenia, ako IoT, pre zvýšenie efektivity vnútropodnikových procesov ale aj pre zvýšenie záujmu spotrebitel'ov. [1] [2] [3] [4]

Oblasti, v rámci ktorých je možné implementovat' IoT sú rôznorodé. Internet vecí je siet' vzájomne prepojených objektov s prístupom internetu, ktoré za využitia rôznych technológií vzájomne spolupracujú a generujú dáta, ktorých analýzou je možné dosiahnut' pridanú hodnotu. V rámci maloobchodu je populárne využívanie vysokofrekvenčnej identifikácie - RFID. S príchodom nových technológií a zariadení, vylepšením senzorov, konektivity a komunikačných technológií ponúka IoT ešte viac riešení, ktoré je možné implementovat' v rámci maloobchodu. Internet vecí je výkonný nástroj, ktorý obchodníkom umožňuje sledovat' nákupné správanie zákazníkov, vytvárat' nové obchodné modely alebo optimalizovat' produktivitu a efektivitu jednotlivých procesov. Implementácia internetu vecí v rámci maloobchodu prináša viditel'nost' a flexibilitu všetkých procesov, rozhodovanie na základe údajov, vylepšenie existujúcich a vytvorenie nových služieb a zvýšenie spokojnosti zákazníkov. Okrem toho umožňujú IoT riešenia obchodníkom získat' alebo zvýšit' svoju konkurenčnú výhodu. Podl'a prieskumu spoločnosti Verizon (2016) vnímajú implementáciu internetu vecí pozitívne aj maloobchodníci, až $77 \%$ maloobchodníkov uviedlo, že implementácia internetu vecí pozitívne mení zákaznícku skúsenost'. Navyše, až 89 \% spoločností v rámci maloobchodu získava lepší prehl'ad o spokojnosti a preferenciách zákazníkov. Pozitívny však nie je vplyv len v rámci vzt’ahov so zákazníkmi. Implementácia má pozitívny vplyv aj na tržby, pričom obchodníci uvádzajú, že implementácia jedného IoT riešenia im priniesla nárast tržieb v priemere o 5-10\%. [5] [6] [7] [8]

Implementáciu IoT a d'alších high-tech riešení je možné využit' aj v prospech podpory udržatel'nosti a ochrany životného prostredia. Európsky parlament definuje udržatel'ný rozvoj ako ,zlepšovanie životnej úrovne a blahobytu l’udí v medziach kapacity ekosystémov pri zachovaní prírodných hodnôt a biologickej rozmanitosti pre súčasné a budúce generácie“. Podl'a výskumu Harvard Law School, až 78\% spoločností z rebríčka Fortune 500 implementovalo štandardy udržatel'nosti. Okrem toho popredné značky v oblasti módy podpísali dohodu o zlepšení udržatel'nosti v tomto sektore. Implementáciou IoT riešení pre monitoring, prediktívnu údržbu, vzdialené ovládanie alebo energetický manažment v rámci výroby, dopravy a predaja produktov je možné prispiet' k zníženiu energetickej náročnosti a uhlíkovej stopy. Zariadenia a platformy IoT sú schopné spoločnostiam napĺn̆at' ciele udržatel'nosti a znížit' tak dopad na životné prostredie. [9] [10]

Dôležitý, napríklad pri rozhodovaní podnikov, je aj pomer l'udí, ktorí nakupujú online a offline. Európsky štatistický úrad v roku 2020 realizoval prieskum zameraný na l’udí vo veku od 16 do 74 rokov nakupujúcich online v rámci krajín Európskej únie. Výsledky prieskumu znázorňuje obrázok 1., pričom vychádzajú z odpovedí 139073 respondentov z jednotlivých krajín Európskej únie. Výsledky komparácie členských krajín Európskej únie v oblasti online nakupovania zobrazujú kol'ko percent obyvatel'ov v jednotlivých krajinách za posledných 12 mesiacov nakupovalo online. Lídrom v rámci porovnania je Dánsko, kde až $89 \%$ obyvatel'ov z danej vekovej skupiny za posledných 12 mesiacov nakupovalo online. Medzi krajiny s najväčším podielom l'udí nakupujúcich online patrí aj Holandsko a Švédsko. [11]

Z pohl'adu priemeru Európskej únie nakupovalo online $64 \%$ obyvatel'ov. Detailnejší prehl'ad online nakupovania $\mathrm{v}$ rámci Európskej únie zobrazuje obrázok 1. V porovnaní s rokom 2019 sa priemer obyvatel'ov nakupujúcich online v rámci EÚ zvýšil o $3 \%$ a v porovnaní s rokom 2009 až o 32 \%. Z prieskumu Európskeho štatistického úradu vyplýva, že $62 \%$ obyvatel'ov Slovenskej republiky v roku 2020 nakupovalo online.[11] 


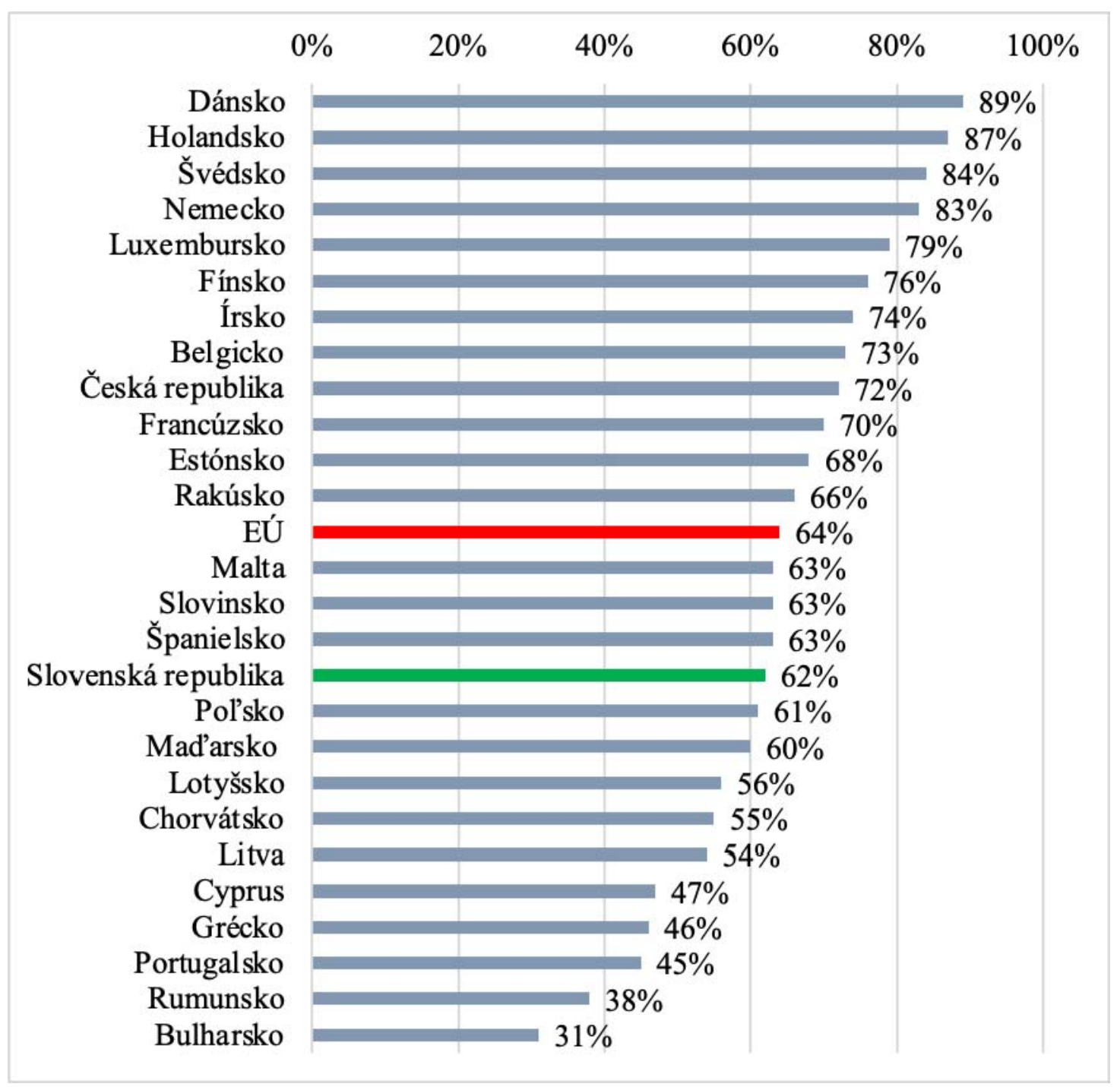

Obrázok 1. Online nakupovanie v EÚ

Zdroj: [11]

\section{Ciel' a metodológia}

Hlavným ciel’om príspevku je analyzovat' vplyvy, ktoré majú v rámci spotrebitel'ského správania najväčšiu váhu pri nákupe športového vybavenia a povedomie respondentov o implementácií IoT riešení. Analyzované tiež bolo povedomie respondentov o koncepcii udržatel'nosti v maloobchode. Dosiahnutie tohto ciel'a bolo realizované prostredníctvom primárneho marketingového výskumu. Výskum bol realizovaný na vzorke respondentov vo veku 18 a viac rokov. Spodné vekové ohraničenie bolo stanovené na základe štatistík spoločnosti TopSki, z ktorých vyplýva, že zastúpenie zákazníkov vo veku menej ako 18 rokov je minimálne. Marketingový výskum bol realizovaný v období marec až máj 2021. Údaje boli zbierané prostredníctvom metódy dopytovania a excerpovania. Dopytovanie bolo realizované elektronicky prostredníctvom online dotazníka, ktorý bol vytvorený na internetovej stránke www.typeform.com. Dotazník pozostával zo sedemnástich uzatvorených identifikačných a meritórnych otázok. Výskumu predchádzalo testovanie pre odhalenie nežiaducich chýb v dotazníku, ktorého sa zúčastnilo 30 respondentov. Získané údaje boli analyzované prostredníctvom programu Microsoft Office Excel. Na základe výpočtu výberovej vzorky 
bolo potrebné získat' odpovede od minimálne 385 respondentov. Na výpočet výberovej vzorky respondentov bol použitý nasledujúci vzorec:

$$
n \geq \frac{N * t_{1-\frac{\alpha}{2}}^{2} * \sigma^{2}}{(N-1) * \Delta^{2}+t_{1-\frac{\alpha}{2}}^{2} * \sigma^{2}}
$$

kde $\mathrm{n}=$ minimálna vel'kost' vzorky; $\mathrm{t} 1-\alpha / 2=$ kritická hodnota určená z tabuliek; $\sigma 2=$ rozptyl; $\Delta=$ maximálne prípustné rozpätie chýb; $\mathrm{N}=$ vel'kost' základného súboru. Respondenti boli oslovení prostredníctvom sociálnej siete Facebook. Úspešne vyplnilo dotazník 391 respondentov.

\section{Výsledky}

Najviac respondentov (72\%) uviedlo, že športové vybavenie a doplnky nakupujú najčastejšie $0-1$ krát za mesiac. $Z$ celkového počtu respondentov uprednostňuje pri nákupe športového vybavenia a doplnkov internetové predajne $56 \%$ respondentov. V skupine respondentov, ktorí uprednostňujú internetové predajne, mala najväčšie zastúpenie veková skupina 18-24. V prípade respondentov uprednostňujúcich kamenné predajne boli najpočetnejšou skupinou respondenti vo veku 45-54. Porovnanie vekových skupín znázorňuje obrázok 2.

\begin{tabular}{|c|c|c|c|c|c|c|c|}
\hline \multirow{2}{*}{$\begin{array}{l}\text { Internetová predajňa } \\
\text { Kamenná predajňa }\end{array}$} & \multicolumn{3}{|c|}{82} & 60 & \multicolumn{2}{|c|}{$\begin{array}{lll}40 & 15 & 113\end{array}$} & \\
\hline & 32 & 32 & 31 & 51 & 20 & 14 & \\
\hline \multicolumn{2}{|c|}{$\begin{array}{c}0 \\
18-24\end{array}$} & $\begin{array}{r}50 \\
25-34^{5}\end{array}$ & $35-44$ & $\begin{array}{l}100 \\
45-54\end{array}$ & $\begin{array}{c}150 \\
55-64\end{array}$ & $65+200$ & 250 \\
\hline
\end{tabular}

Obrázok 2. Výber typu predajne v závislosti od veku

Zdroj: Autor.

Medzi najčastejšie faktory uprednostnenia kamennej predajne patria možnost' reálne vidiet' a vyskúšat' si produkty, odborné poradenstvo a pozitívna predchádzajúca skúsenost'. Respondenti uprednostnili nákup prostredníctvom internetovej predajne najčastejšie na základe ceny, možnosti rýchleho porovnania ponúk viacerých predajcov a vyhnutiu sa osobného kontaktu s odbornými asistentmi predaja. Respondenti najčastejšie uviedli, že pri výbere konkrétnej internetovej predajne má najväčší vplyv cena a dostatočné znázornenie a popis produktov. Prehl'ad vplyvov na výber internetovej predajne znázorňuje tabul'ka 1.

Tabul'ka 1. Vplyv faktorov na výber internetovej predajne

\begin{tabular}{|c|c|c|}
\hline Odpoved' & Počet & \% \\
\hline Cena & 104 & 27 \\
\hline Ponuka produktov & 48 & 12 \\
\hline Kvalita produktov & 32 & 8 \\
\hline Recenzie & 53 & 5 \\
\hline Doba doručenia & 21 & 3 \\
\hline Cena doručenia & 12 & 6 \\
\hline Prehl'adnost' & 24 & 25 \\
\hline Dostatočný popis & 97 & \\
\hline
\end{tabular}

Zdroj: Autor.

Z celkovej vzorky respondentov má skúsenost' s IoT riešeniami v rámci maloobchodu $33 \%$ respondentov, avšak väčšina respondentov získala skúsenost' s takýmito riešeniami 
v zahraničí. Záujem o implementáciu IoT riešení v rámci kamenných a internetových predajní by malo až $80 \%$ respondentov, pričom až $32 \%$ z týchto respondentov sa už stretlo s IoT riešeniami $\mathrm{v}$ rámci maloobchodu. Postoj respondentov $\mathrm{k}$ implementácií $\mathrm{IoT} \mathrm{v}$ rámci maloobchodu znázorňuje tabul'ka 2.

Tabul'ka 2. Záujem respondentov o IoT v rámci maloobchodu

\begin{tabular}{|c|c|c|}
\hline Odpoved & Počet & \% \\
\hline Áno & 189 & 48 \\
\hline Skôr áno & 125 & 32 \\
\hline Skôr nie & 49 & 13 \\
\hline Nie & 28 & 7 \\
\hline
\end{tabular}

Zdroj: Autor.

Dôležité však je aj to, či by implementácia IoT riešení pozitívne ovplyvnila nákupné správanie respondentov pri výbere typu predajne, kde budú nakupovat'. Implementácia IoT riešení by mala pozitívny vplyv na $66 \%$ respondentov. V prípade rozhodovania sa respondentov len medzi internetovými predajňami by mala implementácia IoT riešení pozitívny vplyv len na $38 \%$ respondentov. Detailnejší prehl'ad postojov respondentov znázorňuje tabul'ka 3.

Tabul'ka 3. Vplyv IoT riešení na výber predajne

\begin{tabular}{|c|c|c|}
\hline Odpoved' & Počet & \% \\
\hline Áno & 63 & 16 \\
\hline Skôr áno & 86 & 22 \\
\hline Skôr nie & 97 & 25 \\
\hline Nie & 145 & 37 \\
\hline
\end{tabular}

Zdroj: Autor.

Druhá čast' primárneho výskumu bola zameraná na koncept udržatel’nosti. Z celkovej vzorky respondentov nakupovalo v predajni, ktorá integrovala do svojej stratégie koncept udržatel'nosti len $21 \%$ respondentov, $48 \%$ respondentov v takejto predajni nenakupovalo a $31 \%$ respondentov na otázku nevedelo odpovedat'. Udržatel'né produkty v minulosti kúpilo $36 \%$ respondentov, $31 \%$ respondentov takýto produkt nekúpilo a $33 \%$ respondentov na otázku nevedelo odpovedat'.

V rámci rozhodovania, či respondent bude realizovat' nákup $\mathrm{v}$ internetovej alebo kamennej predajni, až $62 \%$ respondentov uviedlo, že koncept udržatel'nosti by nemal vplyv na ich rozhodnutie. V prípade, že by respondent realizoval nákup v internetovej predajni, koncept udržatel'nosti by pri výbere konkrétnej internetovej predajne určite neovplyvnil až $67 \%$ respondentov. Postoj respondentov znázorňuje tabul'ka 4.

Tabul'ka 4. Vplyv konceptu udržatel'nosti na výber internetovej predajne

\begin{tabular}{|c|c|c|}
\hline Odpoved' & Počet & \% \\
\hline Áno & 43 & 11 \\
\hline Skôr áno & 31 & 8 \\
\hline Skôr nie & 55 & 14 \\
\hline Nie & 262 & 67 \\
\hline
\end{tabular}

Zdroj: Autor. 
Až $29 \%$ respondentov uviedlo, že spotrebitel'ské správanie pri výbere internetovej predajne by bolo pozitívne ovplyvnené faktormi ktoré znižujú negatívny dopad na životné prostredie. Jedná sa o faktory ako napríklad predaj udržatel'ných produktov, ekologickejšia doprava alebo ekologickejšie balenie produktov. Prehl'ad postojov respondentov k ovplyvneniu faktormi, ktoré znižujú dopad na životné prostredie znázorňuje tabul'ka 5.

Tabul'ka 5. Vplyv ekologickejších faktorov na výber internetovej predajne

\begin{tabular}{|c|c|c|}
\hline Odpoved' & Počet & \% \\
\hline Áno & 141 & 36 \\
\hline Skôr áno & 106 & 27 \\
\hline Skôr nie & 54 & 14 \\
\hline Nie & 90 & 23 \\
\hline
\end{tabular}

Zdroj: Autor.

Respondenti uviedli, že ich spotrebitel'ské správanie pri výbere internetovej predajne by boli ovplyvnené implementáciou IoT riešení (38\%), konceptom udržatel'nosti (19\%) alebo faktormi, ktoré znižujú dopad na životné prostredie (63\%). Mali by však tieto faktory väčší vplyv na rozhodovanie respondentov ako faktory uvedené v tabul'ke 1? Respondenti mali na výber odpovede áno a nie. Až 71 \% respondentov uviedlo, že udržatel'nost', IoT riešenia a ekologickejšie alternatívy, by nemali väčší vplyv na rozhodnutie ako faktor, ktorí označili v tabul'ke 1 .

\section{Záver}

Podl'a Yan, X., spotrebitelia najčastejšie uprednostnia kamennú predajňu najmä na základe možnosti používania produktu ihned' je po jeho zakúpení, a možnosti vyskúšania si produktu. Internetovú predajňu respondenti uprednostnia najčastejšie na základe pohodlnosti nákupu a možnosti objednat' si produkt odkial'kol'vek a kedykol'vek. Najčastejšie respondenti nakupujú akékol'vek oblečenie a kozmetiku. Podl'a prieskumu Európskej komisie z roku 2020, slovenskí spotrebitelia najčastejšie nakupujú online oblečenie a športové vybavenie, pričom spotrebitelia realizovali online nákupy najčastejšie vo výške 100-500€. [11] [12]

$\mathrm{Na}$ základe realizovaného primárneho výskumu je však možné konštatovat', že v prípade slovenských spotrebitel’ov sa nejedná primárne o pohodlnost' nákupu prostredníctvom internetu ale najdôležitejším faktorom je cena, ktorá je vo väčšine prípadov nižšia ako v kamenných predajniach. V prípade nákupu športového vybavenia je však situácia špecifická $v$ tom, že kvalitné vybavenie od renomovaných značiek je väčšinou finančne náročnejšie. Spotrebitelia pravdepodobne pri investícii väčšej sumy majú potrebu si produkt vyskúšat' a vidiet' ho naživo. Práve tento aspekt môže hrat' dôležitú úlohu v tom, že rozdiel medzi počtom l'udí nakupujúcich športové vybavenie online, nie je radikálne vyšší vzhl'adom na počet l'udí nakupujúcich $\mathrm{v}$ kamenných predajniach. Ďalším dôvodom môže byt' konzervatívnost' slovenských spotrebitel'ov, ktorí v porovnaní krajín Európskej únie nakupujú online výrazne menej. [11] [12]

Na základe prieskumu Európskeho štatistického úradu je možné konštatovat', že vo všeobecnosti až $62 \%$ obyvatel'ov Slovenskej republiky v roku 2020 nakupovalo online. Z primárneho výskumu vyplýva, že v rámci nakupovania športových potrieb a doplnkov uprednostňuje nakupovanie prostredníctvom internetových predajní $56 \%$ respondentov. Najčastejšími dôvodmi výberu internetovej predajne sú cena, možnost' rýchleho porovnania ponúk viacerých predajcov a vyhnutie sa kontaktu s asistentmi predaja. Ak respondenti uprednostnili nákup športového vybavenia a doplnkov prostredníctvom kamennej predajne, najčastejšie to bolo $\mathrm{z}$ dôvodu možnosti vyskúšania si produktov, pozitívnej skúsenosti 
a odborného poradenstva. Väčšina respondentov by nebola ovplyvnená implementáciou konceptu udržatel'nosti. Naopak, väčšinu respondentov by pri výbere konkrétnej internetovej predajne pozitívne ovplyvnila implementácia IoT riešení a faktory, ktoré majú pozitívny vplyv na zníženie negatívnych vplyvov na životné prostredie. Napriek pozitívnemu vplyvu na respondentov pri výbere internetovej predajne, by tento vplyv bol nižší ako vplyv tradičných faktorov, ako cena, ponuka produktov alebo znázornenie a popis produktov.

\section{Literatúra}

[1] MADLEŇÁK, R.: Elektronický obchod, Žilina : Žilinská univerzita, 2004.,160 s., ISBN 80-8070-192-X.

[2] JUCHA,P. Analýza vplyvov jednotného digitálneho trhu na spotrebitel'a, Žilina: Žilinská univerzita, 2017, 50 str.

[3] TERZI, N.: The impact of e-commerce on international trade and employment. Procedia - Social and Behavioral Science. 2011. str. 745 - 753.

[4] POONG, Y. - ZAMAN, K. - TALHA, M.: E-Commerce Today and Tomorrow: A Truly Generalized and Active Framework for the Definition of Electronic Commerce. ICEE '06: Proceedings of the 8th international conference on Electronic commerce: The new e-commerce: innovations for conquering current barriers, obstacles and limitations to conducting successfull business on the internet. 2006. str. 553 557. Dostupné na: https://dl.acm.org/doi/abs/10.1145/1151454.1151459

[5] The Internet of Things (IoT) in retail industry - evolutions and use cases. Dostupné na internete: https://www.i-scoop.eu/internet-of-things-guide/internet-things-retail-industry

[6] Cong, W., Li, BB., Zhang, QT. Internet of Things: Business Economics and Applications. Review of business, 41(1), str. 15-29, 2021.

[7] Gazis, A. What is IoT? The Internet of Things explained. Academia Letters, 1003, 2021.

[8] Gannavaram, VTK., Kandhikonda, UM., Bejgam, R., Keshipeddi, SB., Sunkari, S. A Brief Review on Internet of Things (IoT). International Conference on Computer Communication and Informatics, 2021.

[9] Habel, S., Habel, E. Policy coherence for sustainable development and environmental security: A case study of European Union policies on renewable energy. Environmental policy and governance, 2021.

[10] Lukomnik, J. State of Sustainability and Integrated Reporting, 2018. Dostupné na internete: https://corpgov.law.harvard.edu/2018/12/03/state-of-integrated-andsustainability-reporting-2018/\#comment-1144042

[11]E-commerce statistics for individuals. 2020. Dostupné na: https://ec.europa.eu/eurostat/statistics-explained/pdfscache/46776.pdf

[12] Yan, X. Research on Consumers ' Attitudes towards Online and Offline Shopping. E3S Web of Conferences, 218, 2020. 